\title{
A Psychological Discourse of Genocide in Veronique Tadjo's The Shadow of Imana: Travels in the Heart of Rwanda
}

\author{
Abdullahi Kadir Ayinde \\ Department of English, Faculty of Arts, University of Ilorin, Ilorin, Nigeria \\ Email address: \\ kadiraabdul@yahoo.com \\ To cite this article: \\ Abdullahi Kadir Ayinde. A Psychological Discourse of Genocide in Veronique Tadjo's The Shadow of Imana: Travels in the Heart of \\ Rwanda. International Journal of Science and Qualitative Analysis. Vol. 7, No. 1, 2021, pp. 35-40. doi: 10.11648/j.ijsqa.20210701.16
}

Received: March 18, 2021; Accepted: April 2, 2021; Published: June 30, 2021

\begin{abstract}
This essay is a psychological discourse of genocide and its traumatic effects on the author, fictional characters and readers in Veronique Tadjo's The Shadow of Imana: Travels in the heart of Rwanda. Memory is the essential aspect of the psychological discourse that Tadjo employs as a tunnel connecting the past to the present. The fiction exposes how the genocide causes personal turmoil that creates psychological and emotional breakdown among the victims. The objectives of the study were to examine how the lives of the victims of the war and even survivors had been beaten horribly out of shape by the constant blow of inhumanity. It also examined the application of memory as cathartic in the process of bringing healing to a chaotic and traumatic past and as the individual's means of coming to term with personal, family, social and political experiences that have refused to be harmonized into an acceptable past. The paper specifically deployed the Charles Mauron's pschocriticism, a variant of Sigmud's psychoanalysis, to unravel the mimetic and cathartic representation of dreams and tortures as revealed by metaphors and symbols in the memoir. These metaphorical networks are significant for latent inner realities. The study concluded that the cruelty and human brutality of the genocide in Rwanda exceeded worst expectations. The author aroused the psychological emotions of the fictional characters and transfers same to the readers by creating a cinematographic account of the horrible situation. It also reveals how memory and imaginative fiction are interwoven to provide a connection between the past and present.
\end{abstract}

Keywords: Psychocriticism, Genocide, Trauma, Characters, Metafiction

\section{Introduction}

This paper employs Charles Mauron's psychocriticism [10], a variant of Sigmud Freud's psychoanalysis, to study the dream, memory and trauma of Rwanda genocide of 1994 in the memoir and metafiction of Veronique Tadjo's The Shadow of Imana: Travels in the heart of Rwanda [16]. The psychological effects of the genocide and its impact on human condition in Rwanda and indeed Africa have apparently not been adequately studied in the criticism of literature. To grasp the gravity of the psychological trauma of this genocide, it is well appropriate to examine how Tadjo narrates the pathetic situations of the characters of the massacre through metaphorical and symbolical aesthetics. This exercise in criticism will establish a novel perspective for grapping the psychological impact of the wars on the human lives in Rwanda. Akinwale [3] argues that war can be referred to as conflict aggravated beyond control. A resort to war is usually a result of ideological, religious or racial differences. War is synonymous to ruin, bloodshed and murder.

Similarly, Fornari [8] opines that war arises from the external projection of an internal danger in the face of an alleged external persecutory entity, which compels individuals to destroy in order to survive.

\section{Psychological Criticism}

Kennedy and Dana [9] posit that modern psychology has had a great influence on literature and literary criticism. The psychoanalytic theory of Sigmud Freud transformed the notions of human behaviour by exploring new and 
controversial areas such as wish fulfillment, sexuality, the unconscious and repression. Freud's most fundamental contribution to literary criticism was his elaborate demonstration of how human mental process was unconscious. His theory of human cognition asserts that much of what we forget is actually stored deep in the subconscious mind, including painful traumatic memories from childhood that have been repressed.

Psychological criticism has many variants and proponents, some of which are Freudian, Jungian, Lacan, Mauron, etc. However, they generally often employ three approaches. First, all psycho critics investigate the creative process of the arts, especially as it relates to mental function. Such interrogation may also focus on the effects of a literary text on the reader. The second approach involves the psychological study of a particular writer. Most modern literary biographers employ psychology to understand their subject's motivations and behaviours. The third approach is the analysis of fictional characters. While psychological criticism examines the surface of the literary text, it also speculates on what lies beneath the text- the unspoken or perhaps even unspoken memories, motives and fears that covertly shape the work, especially in fictional characterization.

In the Wikipedia [14], it has been made clear that the object of psychological criticism, in its simplest form, can be a psychoanalysis of the author or of a particular interesting character in a given work of literature. This approach closely follows the analytic interpretative process outlined in Freud's The Interpretation of Dreams and other works. Critics may view the fictional character as psychological case studies, attempting to identify such Freudian's concepts as the Oedipus complex, Slips, Id, ego and superego and show how they influence the thoughts and behaviours of fictional characters. In the submission of Abrams and Harpham [1]

Freud had developed the dynamic form of psychology that he called psychoanalysis as a procedure for the analysis and therapy of neurosis, but soon expanded it to account for many development and practices in the history of civilization, including warfare, mythology and religion as well as literature and the other arts.

Apparently, Freud wrote several essays on literature, which he used to study the psyche of authors and characters, to explain narrative miseries, and develop new concepts in psychoanalysis. Similarly, early psychoanalytic literary critics often treat text as if it were a kind of dream. The critic analyse the language and symbolism of a text to reverse the process of the dream work and arrive at the underlying latent themes. In 1993, Charles Mauron [10] conceives a structured method to interpret literary works through the psychological criticism. The tool kits are:

i. The creative process is akin to dreaming awake: as such, it is mimetic and cathartic representation of an innate desire that is best expressed and revealed by metaphors and symbols

ii. Then, the juxtaposition of a writer's works leads the critic to define symbolical themes iii. These metaphorical networks are significant of a latent inner reality

iv. They point at an obsession just as dreams can do. The last phase consists in linking the writer's creation to his own personal life.

Like most psychologically-induced fiction, Tadjo's memoir carries the readers into deserted streets, the unconscious of the militias and their fields of fire, bringing to bear the disparity between a simulated outward bravado and the internal psyche wrangle of the individual, creating a cinematographic account of the situation. Currie [6] asserts that Tadjo narrates the account of the genocide she encounters and shows the manner in which it constantly moves in the present. She also encounters many people and instances that are complex and simple, that are living and alive, in the manner of any grouping of humans in the world.

The presence of the genocide is often muted, repressed or simply less to do with what is happening than it is at other moments. To say that it is absent is false, a misreading but to say that it is the only presence is equally erroneous. This knot, this struggle is one of the ways in which the text opens Rwanda to a reader prepared to do emotional and imaginative work of witness and engagement.

The essay moves to examine the psychology of dreams and traumatic effects of genocide in Tadjo's The Shadow of Imana.

\section{Memory, Dream and Psychological Effects of Genocide in Tadjo's Metafiction}

Memory is an important component of human psychology that defines and characterizes mankind as human. Daniel [7] citing Encarta defines memory as:

a process by which people and other organisms encode, store and retrieve information. Memory allows us to retrieve events from the distant past or from moments ago.

Without memory, life would be a series of disconnected experiences, each one new and unfamiliar. As a tunnel connecting the past to the present, memory serves an important function in helping man connect with his past and continually resolve conflicting emotions from historical experiences.

In 1998, Veronique Tadjo, a prominent Ivorian writer born in Paris, was in Rwanda with a clear mission to study and investigate what had motivated the genocide. Her quasimemoir, quasi-autobiography and metafiction is, therefore, an assemblage of people's life stories, interviews and author's personal reflections on the war, all aesthetically rendered. The memoir is also an embodiment of real stories, dreams, myths and thoughts of man's cruelty to man. It is a psychological account of dreams and trauma of the survivors, the protest of the slained men, women and children, the murderers, prisoners and foreigners. Through the omniscient point of view, the reader psychologically feels the deep pain of the author as well as the intensity of the trauma of her 
fictional character, which can be appropriately studied through psychocriticism.

Currie [6] asserts that Tadjo's memoir is one of the outputs of the project entitled "Rwanda: Writing as a Duty to Memory" sponsored by Arts and Media Association in France. The project brought together some prominent African writers to Rwanda with a view to archive the trauma and pain of the genocide for humanity. The central tenet of the project, therefore, was the concept of memory. It is an engagement and commitment of African artists to document their voices about the killings and pogrom in Rwanda. Tadjo is undoubtedly one of the best fiction writers in Francophone Africa who, in freshness and innovative energy, mingles her travelogue with fictionalized characters. She binds historically factual conversations and imagined dialogue, persistently eliciting a community of memory which she opines all mankind is implicated in and responsible for. In Rwanda, "the dead are screaming still" and Tadjo listens and imagines ways in which her readers and others might listen too, so that the stories of those still screaming might be heard and their tragic histories not repeated" (Currie, [6]).

The Rwanda genocide occurred between 7 April and 15 July 1994 during the Rwanda civil war. During these one hundred days, members of the Tutsi minority ethnic group alongside the moderate Hutu were slaughtered by armed militias. The intensity of the brutality of the massacre shocked humanity globally, though no country intervene to put a stop to the heart-aching killings ever witnessed in Africa in no distant past. Tadjo writes:

While genocide was going on, in South Africa Nelson Mandela was being elected to the highest office. The world preferred to turn its gaze on him to celebrate this historic moment, which marked the real end of apartheid. The world powers knew that massacres were being carried out in Rwanda, but they were slow to react and to admit that what was going on was genocide. (p. 33)

The Wikipedia [15] posits that most of the victims were slaughtered in their villages or towns, many by their neighbours and fellow villagers. Hutu gangs murdered their victims hiding in churches and school buildings. The killing was carried out with machetes, knives and guns. Sexual abuse and violence was perpetuated with an estimated over half a million women and girls forcefully defiled. The genocide had lasting and pervasive effects on Rwanda with nearly a million people brutally killed. Rwanda is a country with a peculiar history and that peculiarity becomes more intriguing and sometimes perplexing as one move from one region to another. The country is made up of just three interrelated tribes namely, Tutsi, Hutu and Twas. Before the advent of the colonial rule, Rwanda had been embroiled in one kind of war or another among the two rivalry ethnic groups; Tutsi and Hutu who, though, have become organically one due to many centuries of inter-tribal marriages and similar communal pattern of living. One of the characters illuminates this bond clearly when he says:

It was 1990 that I really became aware of the division between the Hutu, the Tutsi and the Twas. Before, I hadn't really taken much notice. My mother was a Tutsi and my father a Hutu. My parents sometimes spoke of what had happened in 1959, when the king died and then some massacres took place, but they had never properly explained about the ethnic divide. Now, I believe that it was a taboo subject for them. We chose our friends as we liked and no one ever made any critical comment about that. I had never asked my friends what ethnic group they belonged to. We spoke the same language, we had the same names, we had the same concerns, what should have been the point? Yet, deep down, we knew that our relatives were divided by ethnic hatred and the propaganda of Hutu power. (p. 109)

Tadjo's fiction reveals through the multitude of voices how the war with which Rwanda was ravaged came as a result of the faulty foundations upon which the nation was built. The sectional and ethnic rivalries and differences are also the aftermaths of the same faulty foundation. The memoir offers the shocking revelations of how people were hopelessly divided by the antics of politicians, who were desperate for power. The cruelty and human brutality exceeded worst expectation. As the genocide deteriorated, people die in great numbers-women and children who lack the knowledge of the cause of the crisis.

Mauron's first schema of psychoanalytical criticism considers the creative process as being akin to dreaming awake: as such, it is mimetic and cathartic representation of an innate desire that is best expressed and revealed by metaphors and symbols. This postulation is well in tandem with the narrative structure of Tadjo's metafiction. The Shadow of Imana narrates the stories of Rwanda genocide in a dream-like style and in a way that touches the sublime. For instance, one of the fictionalized characters, according to the narrator says:

The dead man argued, discussed, negotiated to be allowed to remain on earth. But no one reply to him because they were walled up inside their own pain, deafened by their own tears, and their regret. The dead man knocked on doors and windows, but they did not open. He cried: why are you abandoning me? Now I am a corpse and you no longer recognize me. Can you feel my presence among you? (p. 43)

African Fiction and Religion [2] contends that postcolonial fiction is marked by a turn towards an African audience to address African problems. The multiple consciousness of several sides to a story is taken to new heights with a dialogical representation of reality from an even more complex, pluralistic perspective. In Caruth's Unexpected Experience: Trauma, Narrative and History,[4] trauma is considered as "the story of a wound that cries out...that addresses us in attempt to tell us a reality or truth that is not otherwise available". For instance, the disgorged ugly blood of the genocide provides the psychological impetus that inspired this Tadjo's narrative. This account is a psychologically rendition of memory, dream and trauma which derogates and rejects fixation to past pain. It is a fiction which seeks a teleological account of human action. 
Life and war become interchangeable in the narratives. The memoir, like most psychological induced fictions, is a work of recapitulation that skips nothing from the memory. The narrative, as well, invokes emotion and sympathy for the characters. In the words of Nwanku [12], "War produces a pathetically lame and rudderless polity in which all manners of shameless treachery and scams and skull druggery become a way of life".

As the memoir was written four years after the genocide, stories are invariably refracted through memory, and interpretation relies heavily on psychology. The author employs the omniscient narrator in its conventional form. The necessity to explore source of information, the speculations on human motivation, the inwardly projections of anxieties and apprehensions operates in the domain of psychocriticism. The critic becomes the burden of memory that continues to haunt the text. On the actual killings, Tadjo does not write as if she was present but uses interviews and contacts from those who witnessed and survived the carnage as they howled like a helpless animal. Tadjo deploys the genre of reportage because of its ability to unravel potential discrepancies between fact outside the text and reality imaginatively constructed in the memoir. Reportage also introduces multiple voices of characters. The shadow of Imana is an extraordinary story of genocide, which explores killings, rape, redemption, loss, naked power and its wonton abuse, ambition and its destructive aftermath. The narrator contends that:

If I were to say anything to the children about war, I would make them realize that it came from hatred and being over ambitious. It's all very well to be ambitious, but you've got to be realistic too. You mustn't want too much. You've got to be happy with what you can get by honest means. And above all, you must never believe politicians. They don't tell the truth. They've only got their own interest at heart. They make a huge number of people believe that the genocide was in their own interest. They told the peasant farmers they could take lot of things, they would be rich. In a small country, land is scarce and the plots are getting smaller and smaller. They told them they could take the land, the cattle. They encouraged them to do evil things while they were busy looking after their own interest. Now, they've almost all gone, taking their money with them. They're living quietly somewhere, while the poor people are suffering every day. (p. 107)

Patrick Chabal and Jean pascal Daloz (1990) cited in Nyairo [13] have argued that the crisis of modernity reflected in contemporary African political life can only be best understood as the 'instrumentalization of disorder'. They define this concept as the process whereby political actors on Africa seek to maximize their returns on the state of confusion, uncertainty and sometimes chaos, which characterizes most African political landscape.

The thematic focus of this narrative is essentially the fate of the victims of the war whose lives have been beaten horribly out of shape by the persistent blow of inhumanity. Tadjo makes it possible to psychologically see how, given the right or wrong circumstances, human beings can commit the gravest acts of inhumanity.

Nyamata Church: Site of genocide

plus or minus 35,000 dead.

A woman bound hand and foot.

Mankandori. Aged twenty five. Exhumed in 1997.

Married.

Any children?

Her waist are bound, and tied to her ankles. Her legs are spread wide apart. Her body is lying on its side. She looks like an enormous fossilized foetus. She has been laid on a dirty blanket, in front of carefully lined up skulls and bones scattered on a mat. She has been raped. A pickaxe has been forced into her vagina. She died from a machete blow to the nape of her neck... She is there as an example, exhumed from the ditch where she had fallen with others bodies. On show so that no one can forget. A mummified victim of genocide. Remnants of hair are still attached to her skull. (p. 11)

Many scenes in the memoir reflect this horrifying memory. The narrative is replete with numerous examples of people massacred brutally. The attackers appear distinctly non-human. The reader wonders, are these militias human beings or beasts? The plot plunged us psychologically into the intensely sensorial narrative whereby the victims could have been anyone caught up in any of the bloody civil wars that have ravaged Rwanda. This psychological effect is clear, for the reader the past is much more than a memory. It is not something that only exists in the tortured mind of those who live through the genocide; it is presence in the present. The past does not go away as easily as its categorization. In daily life a link is established between the people and the spirits of those who have died. Of course, the dead include those who were cut down in 1994 when chaos engulfed this small country and the world watched, shocked, horrified but inactive. Genocidal killings started when soldiers, police and militia executed key Tutsi and moderate Hutu military and political leaders following the assassination of the President Juvenal Habyarimana on 6 April, 1994. The narrator believes that:

A military intervention force of modest proportions could have stopped the extremists and quickly put an end to their plans. Instead, the United Nation balked at playing their part. In the end, it was France who became involved on the ground. But what role did France play? Through Operation Turquoise, the French soldiers saved lives, that are certainly true, but they also made it possible for a large number of murderers to escape using the safe humanitarian zone as a protected passage. Consequently, it can be said that France and Belgium continued until the very end to support a genocidal regime, because as far as they were concerned, only the Hutu ethnic majority could guarantee democracy in Rwanda. (p. 33)

As far as Tadjo's narrative is concerned, the brutal killings in Rwanda and its psychological impact globally were without a shadow of doubt, the result of political maneuvering of the elites and politicians, who in order to retain power, created a climate of hatred and gulf by urging 
the Hutu ethnic majority against the Tutsi minority. In unrelenting bleakness of the characters, it is quite possible to envy those already murdered. People tried to escape but eventually died brutally in a variety of ways. One of the survivors says" in my head I can still hear the words of the presenters":

Fight! Crush them! Up and at 'em! With your spears, your sticks, your rifles, your swords, stones, run them through, these cockroaches, enemies of democracy, show you know how to defend yourselves, give your soldiers some encouragement. If you are a farmer and you hear shots, stop your work and go and fight. You've got to be a farmer and a soldier at the same time! (p. 105)

The victims died in hundreds of thousand as they were searched for in every area, every hill, and every neigh bourhood. Quite a lot of the narratives are laden with a dream driven metaphors. The dead were paying regular visits to the living and when they were with them, they would ask why they had been killed. The town streets were filled with spirits moving around, whirling in the stifling air. They jostled the living, clambered on their backs, danced around them, followed them through the crowded alleyways...The dead would have liked to speak but no one could hear them. The spirits were in every household. You could feel them as they scurried past people. (p. 41)

The bulk of African narrative texts are motifs of pain, anguish and impoverishment. According to Mark [11] in The Journal of Pan African Studies (2018) more often than not, African novelists interrogate the colonial exegesis that created the invented community called the nation in Africa. The mindset is mostly on the perennial dissonance that creates tensions in the nation. Scrutinizing the text, what is visible is the power of mind that has remarkably found congruence between prodigious artistic correlation and objective correlation.

Chabwera, [5] however, provides a refreshing perspective to the horrible memory of the genocide in Rwanda. She contends that Tadjo's memoir moves further beyond the narrative of the genocide as a glimmer of hope emerged from the memoir that the survivors indicated the resolve to rebuild their lives and their nation. Their narratives also demonstrated the gradual but steady process of healing. The stories revealed the people's determinations to forgive the past in order to create a future for the living and unborn generations. Rwanda people envisioned a future in which the gory events of the past are not forgotten or erased from the memory but used to provide an archive from which lessons can be learnt.

The pain of the genocide will definitely haunt Rwanda and the world for a long time, but one needs to read the determination of the people to start again. One must acknowledge the people's belief in the importance of peace, because, the popular opinion is that it will make possible the process of forgiveness. The mingling of the more distant and more recent past is demonstrated in the very structure of the book since Tadjo interlaces horrific accounts of the massacre with poetic passages and traditional folktales. This perspective shows not only the hopes and determinations of the survivors to live again but also portrays the beauty of their landscape and illustrates everyday Rwandan practices.

\section{Conclusion}

In conclusion, this paper discusses how Veronique Tadjo's narrative is a compelling blend of real stories, myths, and thoughts on the horror of man's cruelty to man in Rwanda. With a lucid mix of facts and fictions, Tadjo's travel to the scene of the genocide was a part of an effort to have the genocide and its aftermaths archived by a group of African writers, of which, Tadjo emerged a strong voice. The memoir is a psychologically studied to show the pain of the author and her fictional characters, which is one of the major tenets of psychocriticism. In unrelenting bleakness of the characters, the memoir explores the killings, rape, redemption and loss, naked power and its wonton abuse, ambition and its destructive effects in the lives of the victims and survivors of the massacres. Tadjo aesthetically shows how human beings can commit the gravest acts of inhumanity as the narrative becomes replete with examples of people being described as cockroach. The genocide had lasting and profound effects on Rwanda and its neighbouring countries. The scale and extent of the massacres caused worldwide shock, though; the world powers were not quick in their intervention to forcefully stop the killings.

Tadjo's narrative moves beyond a mere chronicling the trauma of the genocide, it demonstrates how the survivors resolve to re-building the ashes of the past and their nation. The story shows a gradual process of healing. It reveals the determination of the people to put the past behind them in order to create a future for their children.

\section{References}

[1] Abrams, M \& Harpham G. 2005. A glossary of literary terms. Canada: Wadsworth Cenage Learning.

[2] African Fiction and Religion/encyclopedia.com $\mathrm{http} /$ www.encyclopedia.com/environment/encyclopediasalma nacs retrieved $29^{\text {th }}$ March, 2021.

[3] Akinwale, Buari. 2020. Identity Construction and Reconstruction in Mandela's long walk to Freedom and Hitler's Mein kampe. Ph.D Protocol submitted to Dept. of English, University of Ilorin.

[4] Caruth, C (1996) Unexpected Experience: Trauma, Narrative and History.baltimore: John Hopkin University press.

[5] Chabwera, Elinettie. 2008."Review of Veronique Tadjo's The Shadow of Imana: Travels in the heart of Rwanda". In Ernest E. (ed). War in African Literature Today. London: James Curry.

[6] Currie, Ian. 2016. Re-membering in stormy time: Veronique Tadjo's The Shadow of Imana: Travels in the heart of Rwanda. South Africa: University of Witwatersrand, Department of Literature, Media and Film Studies. 
[7] Daniel, F. 2018. The image of Africa as memory and Insight in African American Poetry: An appraisal of Yusuf Komunyakka's New Poems. An unpublished Seminal paper, Ahmadu Bello University, Dept. of English, Zaria.

[8] Fornari, Franco (2018) The Psychoanalysis of War. Indiana: Indiana University Press.

[9] Kennedy J \& Giora, D. 2002 An Introduction to Fiction. London: Longman $8^{\text {th }}(\mathrm{ed})$.

[10] Mauron, C. $1963 . \quad$ Psychocriticism https://en.wikipedia.org/wiki/psychanalytic_criticism

[11] Mark, E. 2018. "Studies in postcolonial African Novels." In Journal of Pan African Studies. Vol. 9, no. 10 March.

[12] Nwanku, C. 2008. "The muted index of war in African literature and society". In War in African Literature Today.
[13] Nyairo, Elizabeth. 2018. "Of National Longing and of the Antinomies of the Postcolonial Nation: The Case of Eric wainina's Sawa Sawa". An unpublished Seminal paper, Department of Philosophy, Makerere University, Uganda.

[14] Psychoanalytic literary criticism Wikipedia. https://en.wikipedia.org/wiki/psychanalytic_criticism Retrieved 10th Feb, 2021

[15] Rwanda Genocide Wikipedia https://en.wikipedia.org/wiki/Rwanda_genocideRetrieved 10th Feb, 2021.

[16] Tadjo, V. 2002. The Shadow of Imana: Travels in the heart of Rwanda. Essex: Heinemann. 